\title{
Vill vekst i oversiktsstudier og metaanalyser
}

Oppsummert kunnskap er viktig, ikke minst i medisinen.

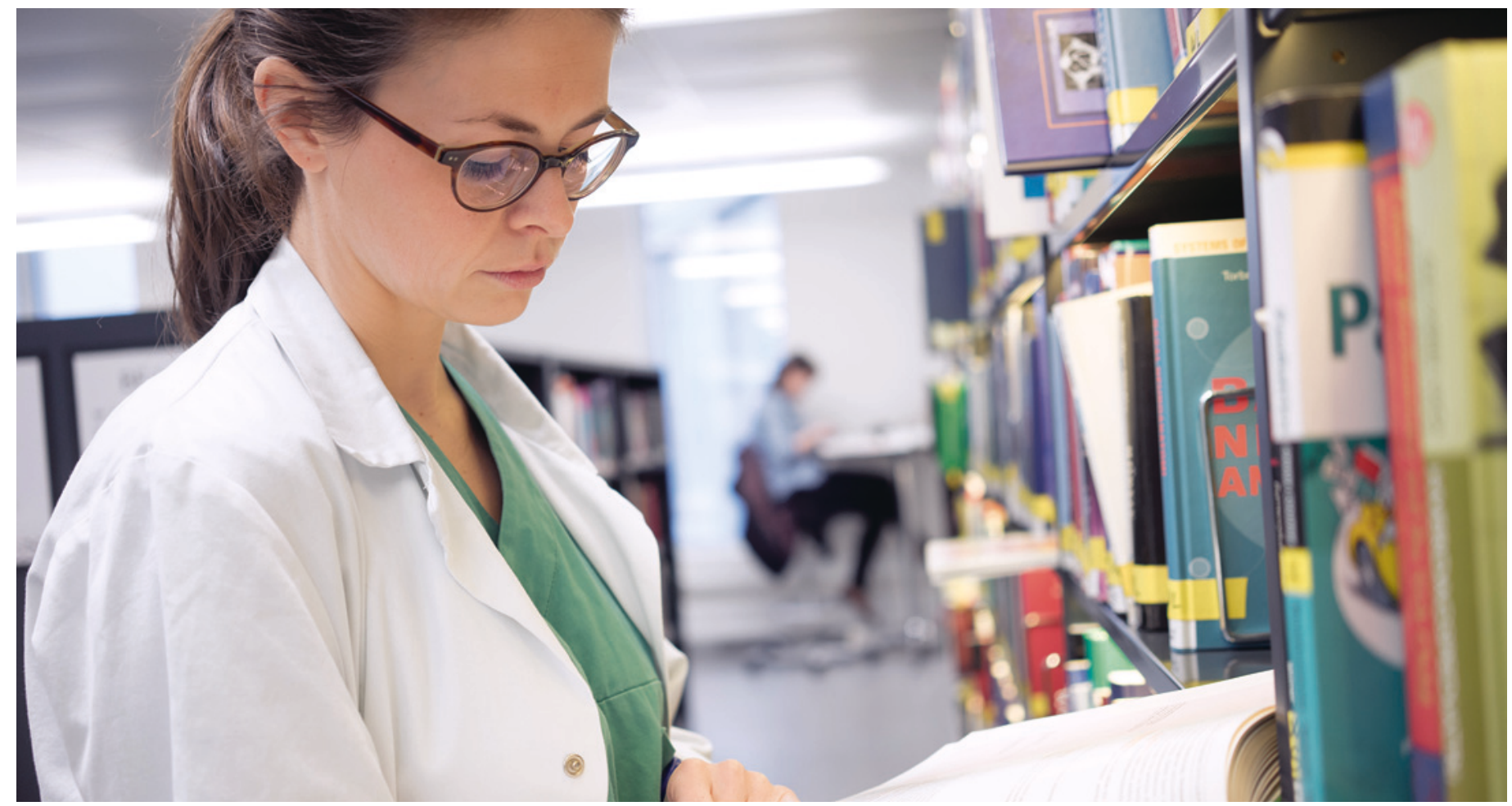

Illustrasjonsfoto: Ole Kristian Losvik

Både pasienter, leger og myndigheter ønsker best mulig kunnskapsgrunnlag, og resultater fra mange studier gir i prinsippet mer pålitelig kunnskap enn enkeltstudier. Utviklingen på dette området har vært enorm siden evidensbasert medisin ble etablert i 1980-årene. I dag er det vitenskapelige grunnlaget for intervensjoner et selvfølgelig vurderingskriterium, og det er grunn til å håpe at evidensbasert medisin bidrar til mer kritisk vurdering av hva vi bør stole på.

Utviklingen har også vært enorm rent kvantitativt. Fra 1991 til 2014 økte antall oppsummeringsstudier med $2728 \%$ og metaanalyser $2635 \%$, mens antall vitenskapelige artikler økte fra 400000 til vel én million. Kanskje er det i dag flere oppsummeringer av randomiserte, kontrollerte studier (RCT) enn nye. Det foregår en masseproduksjon av overflødige, villedende og motstridende oppsummeringsstudier og metaanalyser, hevder John P. A. Ioaniddis i en nylig publisert artikkel (1).

Metaanalyser av bruk av statiner mot atrieflimmer etter hjertekirurgi illustrerer overflødigheten: 11 metaanalyser ble publisert fra 2008 til 2012, der allerede den andre studien viste statistisk signifikant god klinisk effekt. Konklusjonen ble ikke endret i de påfølgende ni analysene, flere av dem tilnærmet identiske. To, kanskje tre, slike analyser virker fornuftig, mens rasjonalet for flere er uklart.

Mer problematisk blir det når analysene er motstridende. Ulike metaanalyser av effekten av antidepressiver viser bemerkelsesverdig sprikende effekter av de samme medikamentene, selv om de som har utført analysene er blant de beste metaanalytikere i verden. Ett og samme medikament ble rangert som alt fra best til nummer ti, et annet fra nest best til nummer ti.

En årsak ligger i datakvaliteten. Mange forsøk er små, de er støttet av legemiddelindustrien, ofte med meningsløst korte oppfølgingsstudier, og viser små kliniske effekter - som oppdragsgiver likevel ønsker å bruke kreativt for å selge sitt legemiddel.

Men det er ikke bare de originale studiene som forklarer spriket. Selv om metaanalyser er det beste verktøyet vi har for å finne ut hvilke tiltak som virker best, er de ikke nøytrale verktøy. Hvilke studier som inkluderes er et springende punkt, og her kan både aka- demiske og pekuniære interesser få utidig innflytelse. Inklusjon av egne studier representerer åpenbar partiskhet, inklusjon av studier for å fremme bestemte legemidler likeså. Metaanalyser er populære i tidsskriftene, de er lettere å få publisert og gir flere publikasjonspoeng. Helsemyndighetene vil gjerne ha dem - som letter tilgang til finansieringskilder.

Upålitelige metaanalyser kan være skadelige gitt den prestisje og betydning slike analyser har fått. For å forbedre kvaliteten er det nødvendig å endre kvalitetskravene, særlig ved å redusere innslaget av private interesser. I tillegg bør kvaliteten på originalstudiene tillegges mer vekt. Transparent design og deling av data er effektive virkemidler for kunnskapsakkumulasjon og kan redusere skjevhet i oppsummerings- og metaanalysene.

\section{Berit Bringedal}

berit.bringedal@legeforeningen.no LEFO - Legeforeningens forskningsinstitutt

\section{Litteratur}

. Ioannidis JPA. The Mass Production of Redundant, Misleading, and Conflicted Systematic Reviews and Meta-analyses. Milbank Q 2016; 94: 485-514. 